\title{
RIAC: Responsible and Informed Arctic Commercialization, A Way Forward
}

\section{Anna M. Zolyniak}

Georgetown University, Walsh School of School of Foreign Service, 3700 O Street NW, Washington, D.C. http://doi.org/10.38126/ISPG170121

Corresponding author: amz52@georgetown.edu

Keywords: Arctic; sustainable commercialization; environmental change; regulations; resource extraction; domain awareness

Executive Summary: In 2019, the Arctic experienced its second warmest year on record, continuing a six-year trend of record-breaking Arctic surface temperatures (Lindsey 2019). Such unprecedented observations have become the new normal in the Arctic and provide new insights into the implications of global climate change. A warming Arctic, however, also presents new opportunities for Arctic commercial development. Such development is in fact quickly evolving from a mere possibility to an on-the-ground reality. Despite the speed of and increasing prospect of Arctic commercialization, however, there has been little to no movement on the part of the United States to enact policies and regulations accounting for it.

Recognizing this gap in U.S. policy, the main objective of this paper is to articulate a possible path towards sustainable Arctic commercialization-one that recognizes and addresses current realities and future potential challenges. To this end, this paper synthesizes a two-pronged policy proposal-referred to as Responsible and Informed Arctic Commercialization (RIAC). RIAC targets the paucity of U.S. Arctic knowledge and regulatory capacity with a clearly articulated framework for implementation. The first prong of the policy addresses the quality of U.S. Arctic domain awareness. The second prong assesses the status of relevant sections of the U.S. Code of Federal Regulations with respect to the unique conditions of the Arctic. The actions encompassed by RIAC's two-pronged structure offer a clear path for the United States to rectify the weaknesses in its current Arctic policy and make sustainable and safe Arctic commercial development possible.

\section{Introduction}

In 2018, Arctic sea ice was younger, thinner, and sparser than ever before (Osborne, Richter-Menge, and Jeffries 2018). That same year, a container ship owed by the world's largest container line, Maersk, made the first-ever trans-Arctic journey-a major milestone for Arctic commercialization (Northam 2018). Projections of a "nearly ice-free Arctic Ocean" within the next few decades have caught the attention of domestic and international businesses, prompting them to explore and seize emerging opportunities to commercialize the Arctic (Masters 2013). Growing global energy demand and the Arctic's rich pool of energy resources have motivated oil and natural gas companies to consider expanding operations into the region (U.S. Energy Information Administration
2011; U.S. Geological Survey 2008; Yalowitz 2012, 32 ). The opening of the Arctic due to declining ice coverage, however, also opens the door for potential accidents, hazardous behavior, and irreversible environmental damage (Bock 2012, 45). Unfortunately, the speed of Arctic environmental change and commercial development has outpaced the ability of the U.S. government to update both its understanding and regulation of the Arctic region (Congressional Research Service 2020, 99-106).

Given the current and ever-increasing extent of Arctic commercialization, the central question faced by the U.S. government has evolved from whether a policy for sustainable Arctic develop is necessary, to how that policy should be structured and implemented. 
Recognizing the need for more-informed Arctic decision making and an updated regulatory corpus that addresses Arctic development, this paper proposes the implementation of the Responsible and Informed Arctic Commercialization (RIAC) policy initiative. The initiative identifies and closes gaps in U.S. Arctic knowledge and regulation. It does so by supporting up-to-date Arctic research and proactive regulatory review and reform. RIAC promotes a course of commercial development in the U.S. Arctic that accounts for environmental concerns and the well-being of Arctic inhabitants. In order to accomplish its overarching objective of influencing sustainable Arctic commercialization, RIAC consists of the following two prongs and associated actions:

- Increase Arctic domain awareness to better respond to rapid changes in the region by:

- Increasing the annual budget for the U.S. National Oceanic and Atmospheric Administration (NOAA), with specific allocation for Arctic development and commercialization research

- Proposing and advocating for the creation of a new Arctic Marine Shipping Assessment (AMSA);

- Identify and close gaps in the U.S. regulatory scheme relating to Arctic commercialization, particularly shipping and resource extraction operations, by:

- Reviewing and updating related sections of the U.S. Code of Federal Regulations (CFR/e-CFR).

Together, these prongs delineate the framework of RIAC. The fulfillment of each prong will achieve the central purpose of RIAC: the establishment of a policy framework that allows U.S. policy makers to ensure safe and sustainable Arctic commercial development. The remainder of this paper is devoted to examining each prong individually.

\section{Prong 1: Increasing Arctic domain awareness}

Creating a safe and sustainable environment for commercial activity in the U.S. Arctic is not feasible without first understanding both the region and the commercial activities in question. How can the United States begin to craft such an environment if it lacks comprehensive knowledge about the area? While it is impossible to know exactly what information is needed to promote safety and sustainability prior to further Arctic commercial expansion, scientists and researchers studying the region have already identified significant gaps in Arctic domain awareness (Huntington 2011). Considering this, the first prong of RIAC is focused on equipping businesses and the U.S. government with the knowledge necessary to safely operate in the Arctic. Improving Arctic domain awareness, which is the "effective understanding of activities associated with the [Arctic] environment," will allow the United States to better understand and respond to changes in the region (Maritime Safety Committee 2010, 1).

\section{i. Increased funding for arctic research}

The first action associated with this prong is to increase funding for National Oceanic and Atmospheric Administration (NOAA) research focused on the implications and potential hazards of Arctic commercialization. This funding would be directed toward NOAA research laboratories and cooperative institutes, which are premier centers for research in the United States (Office of Oceanic and Atmospheric Research 2019). The selection of NOAA as the recipient body of such funding is due to NOAA's established nation-wide research structure focused on environmental issues. Since its inception, the agency has amassed an immense and impressive network of experts and institutes. NOAA has also already conducted valuable Arctic domain awareness research (e.g. NOAA's Arctic Report Cards) (NOAA 2019a) (NOAA 2019b).

NOAA research activity supported by this increased funding should take the approach of environmental intelligence. Following this approach, environmental knowledge will be gathered in a timely manner "suitable for making decisions" associated with the collected information (Mathis 2019a). Targeting weaknesses in U.S. Arctic domain awareness related to Arctic commercialization will allow observations, models, and integrated data to inform policies targeting the creation more effectively and efficiently a safe and sustainable environment for Arctic commercialization (Mathis 2019a). Part of the funding would go toward identifying new gaps in Arctic knowledge. Much of this funding should, however, be put towards areas already identified as lacking in understanding. These areas include, but are not limited to, the following:

- Assessing the impact of oil spills and remediation tactics on Arctic ecosystems; 
- Conducting remediation effectiveness tests north of Prince William Sound and developing more effective remediation technology (National Commission on the BP Deepwater Horizon Oil Spill and Offshore Drilling 2012, 255-279);

- Improving weather and storm surge forecasting;

- Finding ways to reduce noise pollution and its effects on the health and reproductive patterns of marine animals in the Chukchi and Beaufort Seas;

- Identifying potential threats from invasive species (Brigham 2012, 157-173).

Despite NOAA's impressive reputation and research network, the agency's programs require proper financing in order to diagnose and rectify areas of deficient domain awareness. Proper financing is also needed to develop technologies and solutions that address identified environmental concerns. Increasing NOAA research funding would go beyond targeting the paucity of information regarding Arctic commercial activities. It would also signal a U.S. commitment to sustainable and safe Arctic commercialization (Peter G. Peterson Foundation 2018). A critical focus of this research will be on the prevention and remediation of oil spills, which have been cited as the most significant potential environmental threat of Arctic commercialization (Arctic Council 2009, 135).

In recent years, Congress has generally rejected proposed NOAA budgetary cuts, often allocating more funding for certain research activities than requested in the agency's own budget expectations report. In line with this trend, Congress recently rejected the Trump administration's proposal to cut overall NOAA funding by eighteen percent in the 2020 federal budget (Behrens 2019). NOAA's enacted budget for the 2020 fiscal year stands at $\$ 5.35$ billion (American Institute of Physics 2020).

The Trump administration's budget request for the 2021 fiscal year calls for $\$ 4.63$ billion for NOAA funding-a dramatic reduction from NOAA's 2018 budget of $\$ 5.83$ billion (United States Department of Commerce 2020, 7; American Geophysical Union 2020). Based on the spending bills for 2021 in the House of Representatives, however, NOAA would receive $\$ 5.45$ billion (Ecological Society of America 2020). Although Congress's apparent willingness to support
NOAA programs does demonstrate the feasibility of increasing NOAA Arctic research funding, congressional support should not be taken for granted. Funding for rectifying gaps in U.S. Arctic domain awareness will ultimately depend on congressional budgetary allocation decisions (NOAA 2019c). It is therefore crucial to demonstrate to Congress the significant benefits that increased NOAA funding for Arctic domain awareness research would bring.

Clearly demonstrating the relationship between NOAA's research work and RIAC's ultimate goals of Arctic commercial safety and sustainability would help prevent needed funding from being appropriated elsewhere. Justifications for funding would include underscoring how increased awareness of Arctic processes would better inform future funding decisions. NOAA research could also inform government investments in the Arctic by improving the United States' ability to understanding and calculate risk in the region. A clearer understanding of the potential dangers of commercialization would also improve the implementation of commercial regulations in the Arctic. Additionally, improved domain awareness would inform businesses of the potential risks of Arctic activity and would influence the allocation of private research and development (R\&D) funding.

Under the Trump administration, NOAA has called for drastic cuts to its own research funding-especially for Arctic research (United States Department of Commerce 2020, 78). Therefore, parties other than NOAA will likely need to provide Congress with justifications for increased funding. Outside parties could include the National Science Foundation, the National Academy of Sciences, think tanks, and the Union of Concerned Scientists

\section{ii. Updated international Arctic assessments}

The creation of a more recent Arctic Marine Shipping Assessment (AMSA) is the second action associated with the first prong of RIAC. AMSA's focus on marine safety and environmental protection in the context of commercial and environmental change in the Arctic perfectly correlates with the objectives of RIAC, as well as the current six-pronged U.S. Arctic policy (Arctic Council 2009, 97; U.S. Department of State 2017). In 2015, the Arctic Council published an AMSA status report evaluating the success of implemented recommendations made in the original report from 2009 (Arctic Council 2015). The rapid rate 
of change in the Arctic, however, calls for the creation of a new AMSA - not a further evaluation of the 2009 report. The original AMSA contains predictions and estimates only up to 2020; a new AMSA, on the other hand, would provide more relevant and up-todate recommendations for Arctic development. (Protection of the Arctic Marine Environment 2009).

Furthermore, the 2009 AMSA evaluates sea ice behavior from the past three decades (Arctic Council $2009,30)$. A new report would have the advantage of an additional decade of data concerning not only ice patterns, but also biological environmental factors such as the recent northern migration of phytoplankton and whale species (Katz 2018). Additionally, the initial 2009 report was proposed in 2004 (Arctic Council 2009, 2). Based on this timeline, a new AMSA would take roughly five years to complete; however, records are being broken regularly in the Arctic (Fountain and Popovich 2019). This dynamic rate of change requires more than just an evaluation of 2009 models to ensure safe and sustainable Arctic commercial development-it requires new models.

An updated report would focus on how developments and events since 2009 have altered original recommendations and predictions regarding Arctic development. For example, the report should include an assessment of the potential effectiveness of the United National Convention on the Law of the Sea (UNCLOS) - and Article 234 of UNCLOS in particular-as the governing law of the Arctic going forward (United Nations 1982). This assessment should consider the 2016 Chinese rejection of the Hague ruling concerning the South China Sea and the rate of Arctic sea ice melt (Zhang 2017, 440-459; Stokke 2012, 297-311).

The United States should demonstrate leadership and initiative in the creation of a second AMSA by including it in its agenda as an Arctic Council member. Doing so would allow the United States to have a greater say regarding the new report's focus. Such leadership would also clearly articulate U.S. Arctic commitments and interests to other Arctic nations and countries with Arctic ambitions. Both of these effects would improve the prospects of safe Arctic commercial development in the American Arctic by clearly defining U.S. interests and presence in the region.
The United States does not have to wait until it assumes Arctic Council Chairmanship again in 2031 to push this initiative forward (Arctic Council 2020): the creation of an updated AMSA correlates with the outlined Arctic priorities and agenda of the current country possessing the Chairmanship of the Arctic Council-Iceland (Arctic Council Secretariat 2020). As the chair of the Arctic Council, Iceland is responsible for crafting the work plan and program of the Council during the two years of its Chairmanship. According to its Chairmanship Program for 2019 to 2021, Iceland has taken on sustainable development as the overarching theme of its term as chair. Iceland has also vocalized its commitment to promoting safe and sustainable commercial activity in the Arctic, such as increased shipping (Ministry for Foreign Affairs 2019, 5). Furthermore, Iceland held the Chairmanship when the original AMSA was proposed. The United States could therefore propose a new AMSA at a meeting of the Permanent Participants and Senior Arctic Officials and expect to receive strong support from current Arctic Council leadership (Arctic Council 2018b).

Once the initiative is given a green light and approved by consensus, two Arctic Council working groups will begin work on a new report. The Protection of the Arctic Marine Environment (PAME) and Emergency Prevention, Preparedness, and Response (EPPR) working groups will collaborate to produce a new AMSA. The new report should not only update the information of the original report, but also examine gaps in the original assessment and new questions regarding the presence of commercial activity in the Arctic (Protection of the Arctic Marine Environment 2009). Analysis is required to ensure that the research conducted for the report minimally disturbs the Arctic environment. For example, the migratory patterns of Arctic marine life should be monitored to mitigate the adverse effects of noise pollution and collisions (Finnish Ministry of the Environment 1997, 24-26). The final product will have to be approved at an Arctic Ministerial meeting by the Permanent Participants of the Arctic Council (Arctic Council 2009, 2). Since the Arctic Council is only a forum, it will be up to the individual member states to implement its recommendations (Arctic Council 2018a). Nevertheless, the report will provide extremely valuable information regarding of Arctic processes and changes that will help guide safe and sustainable Arctic development. 
Considering that the creation of a new AMSA will be funded by the nations of the Arctic Council, the United States will need to gain their cooperation to accomplish this goal (Arctic Council 2018b). The United States could foster such support by allocating funds for a new AMSA study in the budget for the EPA, which serves as the head of the U.S. delegation to the main funding mechanism of Arctic Council projects (U.S. Environmental Protection Agency 2019). To gain consensus approval for the creation of the report and raise funding, the United States could also produce a press release prior to proposing creating a new report to the Arctic Council (Arctic Council 2018b). This press release could highlight the importance of a new report, including the advantages over another basic evaluation of the 2009 recommendations. For example, rather than simply measuring the effectiveness of governing regimes such as the Polar Code, which was made mandatory in 2017, a new AMSA would also highlight remaining gaps in international Arctic legal infrastructure (International Maritime Organization 2017).

The press release would also call attention to the exceptional rate of change in the Arctic and the need for predictions past 2020. To address these realities, a new AMSA would encompass the latest information regarding resources, shipping routes, melting, ship presence, navigation and communication infrastructure, and governance. This new information would be a notable improvement from the outdated figures and considerations of the 2009 report. For example, at the time of the initial report's publication, there was no Differential Global Positioning System in the Bering Strait Arctic Region. This area will likely be a hotspot for cargo and resource-extracting vessels as the Arctic becomes more accessible (Arctic Council 2009, 109). Given the region's extreme and unpredictable weather conditions, it is important to know whether the technological landscape has changed (Arctic Council $2009,138)$. A press release would underscore how a new report would fill such an information gap.

\section{Prong 2: Improving the U.S. Arctic regulatory regime}

The focus of RIAC's second prong is to improve the current U.S. regulatory regime as it pertains to the Arctic. The goal of this prong is to identify gaps in U.S. regulatory infrastructure directly related to Arctic commercialization and address them. Accounting for current regulatory shortcomings will improve the United States' ability to react to developments and prevent accidents that jeopardize the safety of people living and working in the Arctic. It will also allow the United States to regulate and shape Arctic commercial development in a way that mitigates and potentially prevents the harmful environmental consequences of commercialization.

\section{i. Updating federal regulations}

Due to the lack of Arctic knowledge and the rate of change in the region, the U.S. Code of Federal Regulations (CFR) has yet to account for increasing access to Arctic waters and resources (Mathis 2019a; Arnaudo 2012, 88-90). Safe and sustainable Arctic commercialization will only be achieved if the necessary regulatory framework is implemented to monitor and direct Arctic development. Considering this, the second prong of RIAC calls for a review and revision of relevant CFR titles that directly relate to Arctic commercial development. The implementation of this action would largely be on an agency/departmental level. It would involve governmental agencies, departments, and/or commissions with responsibilities and oversight capacities relevant to such development. To execute this action, this amalgam of governmental offices-referred to collectively as bodies-would review the sections of the CFR that fall under their jurisdiction and are relevant to Arctic commercial development. The initiative for such a review process could come from the office of the president or Congress (Aftergood 2011; Congressional Research Service 2018,1$)$.

Based on a review of the 2014 Government Accountability Office (GAO) Maritime Infrastructure report and an independent assessment of the current CFR, bodies relevant to such a review process were identified and denoted in Appendix A (United States Gov- 
ernment Accountability Office 2014, 1-4, 12; Electronic Code of Federal Regulations). ${ }^{1}$ Although the identified bodies can independently decide how to allocate the assessment and revision of current regulations, a proposed delegation has been included in Appendix B.

The regulatory review process will not only identify gaps in the current U.S. regulatory corpus; it will also fill those gaps using up-to-date information. ${ }^{2}$ This process will rely on additional external recommendations and reports as guidelines. Such reports include the Snow, Water, Ice, Permafrost in the Arctic report, AMSA, Guidelines on Voyage Planning for Passenger Ships Operating in Remote Areas, Arctic Offshore Oil and Gas Guidelines, and the Guidelines for Ships Operating in Polar Waters (Berkman, Arthur, and Vylegzhanin 2012, 371-404).

By using research produced by various agencies, commissions, and organizations-including the Arctic Council, Kawerak, Inc., NOAA, U.S. Army Corp of Engineers, and the Marine Mammal Commissionbodies will be able to formulate specific and detailed Arctic regulations with little room for commercial interests to find loopholes (Kawerak, Inc. 2015; U.S. Army Corp of Engineers 2019; Marine Mammal Commission 2019). Taking a targeted approach towards filling regulatory gaps will allow bodies to address principle concerns regarding Arctic commercialization, such as noise pollution and the increased risk of oil spills (Arctic Council 2009, 108). Other concerns include the exacerbation of Arctic amplification through the release of greenhouses gases and particulate matter, more collisions and commercial interactions with marine life, and the introduction of invasive species (Arctic Council 2009, 140-146; Geiling 2014). The new regulations should focus on the following:

- Managing the types and quality of ships operating in the Arctic (Arctic Council 2009, 71);

- Establishing requirements for Arctic commercial interests to report specific information to the U.S. government,
- Articulating environmental standards of ships and resource-extracting equipment that account for colder temperatures, extreme weather, unpredictable sea-ice flows, and environmental changes (International Maritime Organization 2019; Maritime Safety Division 2010, 3; Arctic Council 2009, 104);

- Setting clear and strict standards for ballast water exchanges that can transport invasive species (Geiling 2014);

- Delineating restricted locales for legal commercial activity;

- Denoting the risks taken on by companies choosing to operate in the Arctic (Artic Council 2009, 104).

Below are four potential examples of a review and revision of existing regulations:

1) NOAA would evaluate 15 C.F.R. $§ 970.701$, focusing on the adverse environmental effects of deep seabed mining regulations and exploration licenses. Based on the evaluation of this regulation, NOAA may determine a need to revise which activities it delineates as having significant environmental ramifications. For example, NOAA's current list of environmentally harmful activities does not mention mining practices that produce noise pollution, which impairs marine animal migratory patterns. Migrating animals include marine mammals that are the staple food source for Alaska Natives and a critical part of the Arctic ecosystem (15 C.F.R. § 970.701).

2) The Department of Defense (DOD) and EPA would join in a partnership assessment of Part 1700 of 40 C.F.R., focusing on marine pollution control and vessel performance standards. Based on this evaluation, the DOD and EPA may determine the need for specific provisions addressing extreme and unpredictable Arctic weather conditions and the lack of emergency resources in the Arctic. Such provisions could delineate standards for limiting the potential for discharge and contamination

\footnotetext{
${ }^{1}$ The author of this paper went through and reviewed relevant titles of the e-CFR and determined, based on a comprehensive understanding of Arctic security and the current and predicted state of Arctic commercialization, which sections of the e-CFR were relevant. Based on this assessment, the author then noted the bodies named as being associated with the identified sections.

${ }^{2}$ As up-to-date as possible, given the inadequacies of U.S. Arctic domain awareness.
} 
in the event of weather damage or an accident. Such discharge could alter the chemical composition of ocean water and affect the functional capacities and reproductive health of marine life ( 40 C.F.R. $§ 1700$ ).

3) The EPA would evaluate Chapter I Subchapter $\mathrm{U}$ under 40 C.F.R. in order to address the implications of particulate matter (PM) on the melting of fast and drift Arctic ice. This assessment could reveal the need for an additional provision under Subchapter U relating to air pollution controls that focus on particulate matter emissions. This new provision would account for the additional environmental consequences $^{3}$ of PM emissions in the Arctic by placing stricter limitations on PM emissions from Arctic commercial operations (40 C.F.R. $\S \S 1026-1074)$.

4) The U.S. Coast Guard, under the Department of Homeland Security, would evaluate its regulations under Chapter I of 46 C.F.R. based on the knowledge of a recent spike in miscellaneous cargo and vessels in the Arctic regions of Alaska. This increase is due to melting coastal sea ice, which creates an opportunity to bypass airport security and engage in illegal shipping activities along the Alaskan coast (46 C.F.R. Ch.I). In order to avoid emboldening a potential "smugglers' paradise," the Coast Guard may determine the need for additional provisions under Chapter I that specifically relate to shipping regulations in the Arctic region (Tingstad et al. 2017, 57-59; 46 C.F.R. Ch.I).

Once areas lacking proper oversight are targeted with new, informed proposals for regulation, the standard procedure of implementing new regulations must run its course before these new proposals can take effect. This procedure includes publishing proposed regulations as Notices of Proposed Rulemaking (NPRM) in the Federal Register (FR) (Office of the Federal Register 2009, 3). Although there will be nothing special about the implementation procedure for regulations pertaining to the Arctic, the importance of providing clear and convincing background information promoting the relevance of Arctic regulations cannot be overstated. Including such information in the supplementary information section of Arctic-related NPRMs will help garner public support for these regulations. Public support could counter potential push-back from lobbyists and assuage political opposition. For example, if Example 3 from above were to be listed in the FR, the EPA should demonstrate the harmful impacts of PM on the Arctic environment and human well-being. Such background information also has important educational value since there is a general lack of public knowledge about the region.

Given the holes in Arctic domain awareness, the bodies could consider holding public hearings and proactively inviting expert input. This would be in addition to the standard public comment period. Incorporating the input of outside experts would improve the quality of the proposed regulations and increase their credibility. Improved credibility will help reduce the chances of a congressional resolution disapproving the regulation (Congressional Research Service $2019 a, 1)$. This would in turn increase the plausibility of a proposed regulation pertaining to safe and sustainable Arctic commercial development coming into force.

\section{Conclusion}

The changes transpiring in the Arctic pose significant issues and demand immediate government attention. Increased commercial activity in a poorly understood environment that lacks proper regulatory oversight is a dangerous recipe for an expensive and unfortunate disaster. RIAC offers a way for the United States to account for current circumstance in the Arctic and proactively prepare the United States and commercial interests for future changes and challenges. By focusing on safety and sustainability, RIAC prioritizes two critical concerns posed by Arctic commercialization. The actions discussed under the two prongs of RIAC do more than simply assess the inadequacies of current U.S. Arctic domain awareness and regulation; they also posit comprehensive, plausible, and effective ways to fill those gaps. Until proactive initiatives such as RIAC are put into effect to tackle one of today's most pressing challenges-environmental security in the Arctic - the safety of U.S. citizens, international businesses, and the global environment will continue to remain at risk.

\footnotetext{
3 The additional environmental consequences referenced here are in addition to the repercussions of such emissions across all regions in the United States.
} 
Appendix A: Regulatory body and U.S. Code of Federal Regulations titles

\begin{tabular}{|l|l|}
\hline Relevant Body & Corresponding CFR Title \\
\hline DHS* & Title 33, Chapter I; Title 46, Chapter I \\
\hline DOC & Title 15; Title 50, Chapters II, IV, VI \\
\hline DOD & Title 40, Chapter VII; Title 46, Chapter II \\
\hline DOE** & Title 18 \\
\hline DOI*** & Title 30, Chapters II, IV, and V; Title 50 \\
\hline DOT*** & Title 46, Chapter II \\
\hline EPA & Title 40 \\
\hline Federal Maritime Commission & Title 46, Chapter IV \\
\hline NOAA & Title 15, Chapter IX \\
\hline
\end{tabular}

*Department of Homeland Security

**Department of Energy

*** Department of the Interior

**** Department of Transportation 
Appendix B: Regulatory body and proposed delegation

\begin{tabular}{|l|l|}
\hline Body & Proposed Inner-body Delegation \\
\hline DHS & U.S. Coast Guard Office of Standards and Evaluation Development \\
\hline DOC & Office of Strategic Planning \\
\hline DOD & Regulatory Program \\
\hline DOE & Federal Energy Regularity Commission \\
\hline DOI & Office of the Executive Secretariat and Regulatory Affairs \\
\hline DOT & Office of Regulation \\
\hline EPA & Office of Regulatory Policy and Management \\
\hline Federal Maritime Commission & Office of the Secretary \\
\hline NOAA & Office of Legislative and Intergovernmental Affairs \\
\hline
\end{tabular}

\section{References}

Aftergood, Steven, ed. 2011. "Presidential Study Directives [PSD]." Federation of American Scientists. Last modified September 26, 2011. https://fas.org/irp/offdocs/psd/index.html.

Air Pollution Controls, 40 C.F.R. $\S \S 1026-1074$ (). Accessed April 20, 2019. https://www.law.cornell.edu/cfr/text/40/chapter-I/subchapter-U.

American Geophysical Union. "CURRENT FUNDING: NATIONAL OCEANIC AND ATMOSPHERIC ADMINISTRATION." American Geophysical Union. Accessed July 22, 2020.

https://www.agu.org/Share-and-Advocate/Share/Stay-Informed/NOAA-Budget.

American Institute of Physics, ed. "Federal Science Budget Tracker." American Institute of Physics. Accessed July 22, 2020. https://www.aip.org/fyi/federalscience-budget-tracker\#tabs-section-noaa.

Arctic Council. "About." Arctic Council. Accessed July 22, 2020. https://arctic-council.org/en/about/.
Arctic Council. "Ambassador David A. Balton Chair of the Senior Arctic Officials." Arctic Council. Accessed April 20, 2019. https://www.arctic-council.org/images/PDF_attachments/US team bios/US Bio Balton.pdf.

Arctic Council. 2018. "The Arctic Council: A backgrounder." Arctic Council. Last modified September 13, 2018. https://arctic-council.org/index.php/en/about-us.

Arctic Council. 2009. ARCTIC MARINE SHIPPING ASSESSMENT (AMSA). Last modified December 2008. https://www.pmel.noaa.gov/arctic-zone/detect/documents/AMSA 2009 Report 2nd print.pdf.

Arctic Council. 2015. "Following up on the Arctic Marine Shipping Assessment." Arctic Council. Last modified October 5, 2015. https://arctic-council.org/index.php/en/our-work2/8-news-andevents/351-following-up-on-the-arctic-marineshipping-assessment. 
Arctic Council. 2018. "Frequently Asked Questions." Arctic Council. Last modified June 6, 2018, https://arctic-council.org/index.php/en/about-us/arcticcouncil/faq.

Arctic Council Secretariat, ed. "ICELANDIC CHAIRMANSHIP." Arctic Council. Accessed July 22, 2020. https://arctic-council.org/en/about/chairmanship/.

Arnaudo, R. V. 2012. "United States Policy in the Arctic" in Environmental Security in the Arctic Ocean. Compiled by The NATO Science for Peace and Security Programme. Edited by Paul Arthur Berkman and Alexander N. Vylegzhanin, 88-90. NATO Science for Peace and Security Series - C: Environmental Security. Cambridge, UK: Springer.

Behrens, J. 2019. "FY20 Budget Request: National Oceanic and Atmospheric Administration." American Institute of Physics.

https://www.aip.org/fyi/2019/fy20-budget-request-national-oceanic-and-atmospheric-administration.

Berkman, P. A and Vylegzhanin A. N. 2012. "Conclusions: Building Common Interests in the Arctic Ocean" in Environmental Security in the Arctic Ocean. Compiled by The NATO Science for Peace and Security Programme. Edited by Paul Arthur Berkman and Alexander N. Vylegzhanin, 371-404. NATO Science for Peace and Security Series - C: Environmental Security. Cambridge, UK: Springer.

Brigham, L. W. 2012. "Environmental Security Challenges and the Arctic Council's Arctic Marine Shipping Assessment" in Environmental Security in the Arctic Ocean. Compiled by The NATO Science for Peace and Security Programme. Edited by Paul Arthur Berkman and Alexander N. Vylegzhanin, 157-173. NATO Science for Peace and Security Series - C: Environmental Security. Cambridge, UK: Springer.

Bock, N. 2012. "Sustainable Development Considerations in the Arctic" in Environmental Security in the Arctic Ocean. Compiled by The NATO Science for Peace and Security Programme. Edited by Paul Arthur Berkman and Alexander N. Vylegzhanin, 45. NATO Science for Peace and Security Series C: Environmental Security. Cambridge, UK: Springer.

Coast Guard, Department of Homeland Security, 46 C.F.R. Accessed April 20, 2019. https://www.law.cornell.edu/cfr/text/46/chapter-I.

Congressional Research Service. 2020, Changes in the Arctic: Background and Issues for Congress, H.R. Rep. No. 116-R41153, at 1 (June. 18, 2020). https://crsreports.congress.gov/product/pdf/R/R41153.
Congressional Research Service. 2019, The Congressional Review Act: Determining Which "Rules" Must Be Submitted to Congress, Doc. No. 116-R45248, at 1 (Mar. 6, 2019). https://fas.org/sgp/crs/misc/R45248.pdf.

Congressional Research Service, 2018. Congress's Authority to Influence and Control Executive Branch Agencies, Doc. No. 116-R45442, at 1 (Dec. 19, 2018). https://fas.org/sgp/crs/misc/R45248.pdf.

Ecological Society of America. 2020. "Federal Budget Tracker." Ecological Society of America. https://www.esa.org/esablog/federal-budgettracker/\#noaa.

Federal Energy Regulatory Commission, ed. "Federal Energy Regulatory Commission." Federal Energy Regulatory Commission. Accessed July 22, 2020. https://www.ferc.gov.

Federal Maritime Commission. "Office of the Secretary." Federal Maritime Commission. Accessed April 20, 2019. https://www.fmc.gov/bureaus offices/office of the secretary.aspx.

Finnish Ministry of the Environment. 1997. "Guidelines for Environmental Impact Assessment (EIA) in the Arctic." Arctic Environment Protection Strategy. Last modified 1997.

https://ceq.doe.gov/docs/get-involved/eiaguide.pdf.

Fountain, H., and Popovich, N. 2019. "March Temperatures in Alaska: 20 Degrees Hotter Than Usual." The New York Times. Last modified April 9, 2019. https://www.nytimes.com/interactive/2019/04/09/climate/alaska-abnormallyhot-march.html.

Geiling, N. 2014. "Arctic Shipping: Good for Invasive Species, Bad for the Rest of Nature." Smithsonian Institution. Last modified May 29, 2014. https://www.smithsonianmag.com/science-nature/global-warmings-unexpected-consequenceinvasive-species-180951573/.

International Maritime Organization. 2017. "Adoption of an international code of safety for ships operating in polar waters (Polar Code)." International Maritime Organization. Last modified 2017. http://www.imo.org/en/MediaCentre/HotTopics/polar/Pages/default.aspx.

International Maritime Organization. "International Convention for the Prevention of Pollution from Ships (MARPOL)." International Maritime Organization. Accessed April 20, 2019.

http://www.imo.org/en/About/Conventions/ListOfConventions/Pages/InternationalConvention-for-the-Prevention-of-Pollutionfrom-Ships-(MARPOL).aspx. 
Katz, C. 2018. "Alien Waters: Neighboring Seas Are Flowing into a Warming Arctic Ocean." Yale Environment 360. Last modified May 10, 2018. https://e360.yale.edu/features/alien-watersneighboring-seas-are-flowing-into-a-warmingarctic-ocean.

Kawerak, Inc. 2015. Letter to U.S. Army Corp of Engineers, Alaska District, "Alaska Deep-Draft Arctic Port System Draft Interim Feasibility Report and Environmental Assessment," April 17, 2015.

https://kawerak.org/wp-content/uploads/2018/04/MP-Kawerak-Comment-Letter-417-2015.pdf.

Legal Information Institute, ed. 2019. "Electronic Code of Federal Regulations (e-CFR)." Cornell Law School. Last modified 2019. https://www.law.cornell.edu/cfr/text.

Lindsey, R. 2019. "2019 Arctic Report Card: Period of record and near-record warmth continues for sixth straight year." Climate.gov. Last modified December 10, 2019. https://www.climate.gov/newsfeatures/featured-images/2019-arctic-reportcard-period-record-and-near-record-warmthcontinues.

Marine Mammal Commission. "About the Commission." Marine Mammal Commission. Accessed April 20, 2019. https://www.mmc.gov/about-the-commission/.

Marine Pollution Control Device (MPCD) Performance Standards, 40 C.F.R. $§ 1700$ (2017). Accessed April 20, 2019. https://www.law.cornell.edu/cfr/text/40/part-1700/subpart-D.

Maritime Safety Committee. 2010. "AMENDMENTS TO THE INTERNATIONAL AERONAUTICAL AND MARITIME SEARCH AND RESCUE (IAMSAR) MANUAL." International Maritime Organization. Last modified May 24, 2010. http://www.imo.org/blast/blastDataHelper.asp?data id=29093\&filename $=1367$.pdf.

Maritime Safety Division. 2010. ENSURING SAFE, SECURE AND RELIABLE SHIPPING IN THE ARCTIC OCEAN. October 15, 2010. http://www.imo.org/en/MediaCentre/HotTopics/polar/Documents/ENSURING\%20SAFE,\%20SECURE\%20AND\%20RELIABLE\%20SHIPPING\%20IN\%20THE\%20ARCTIC\%200CEAN\%20-\%20Article.pdf.

Masters, J. 2013. "The Thawing Arctic: Risks and Opportunities." Council on Foreign Relations. Last modified December 16, 2013. https://www.cfr.org/backgrounder/thawingarctic-risks-and-opportunities.

Mathis, J. 2019. "Domain Awareness and Disaster Responses." Lecture, Georgetown University STIA 364, Washington, DC, March 16, 2019.
Mathis, J. 2019. "Impacts on Indigenous Peoples." Lecture, Georgetown University STIA 364, Washington, DC, February 4, 2019.

Ministry for Foreign Affairs, comp. Together Towards a Sustainable Arctic: Iceland's Arctic Council Chairmanship 2019-2021. Accessed July 22, 2020. https://oaarchive.arctic-council.org/bitstream/handle/11374/2456/Arctic Council-Iceland Chairmanship 2019-2021.pdf?sequence $=1$ \&isAllowed $=\mathrm{y}$.

National Commission on the BP Deepwater Horizon Oil Spill and Offshore Drilling, 2012. "The Challenges of Oil Spill Response in the Arctic" in Environmental Security in the Arctic Ocean. Compiled by The NATO Science for Peace and Security Programme. Edited by Paul Arthur Berkman and Alexander N. Vylegzhanin, 255-279, NATO Science for Peace and Security Series - C: Environmental Security. Cambridge, UK: Springer.

NOAA, ed. "About our agency." NOAA. Accessed April 19, 2019. https://www.noaa.gov/about-our-agency.

NOAA, ed. "Arctic Program." Arctic Program. Accessed April 19, 2019. https://www.arctic.noaa.gov.

NOAA, ed. "NOAA Budget Office." National Oceanic and Atmospheric Administration United States Department of Commerce. Accessed April 19, 2019. https://www.corporateservices.noaa.gov/ nbo/.

Northam, J. 2018. "World's Largest Shipping Company Heads into Arctic As Global Warming Opens the Way." NPR. Last modified August 22, 2018. https://www.npr.org/2018/08/22/640679831/ worlds-largest-shipping-company-heads-intoarctic-as-global-warming-opens-the-wa.

Office of Oceanic and Atmospheric Research. "Cooperative Institutes." Cooperative Institutes. Accessed April 19, 2019. https://ci.noaa.gov.

Office of Standards Evaluation and Development. "Standards Evaluation and Development." United States Coast Guard U.S. Department of Homeland Security. Accessed April 20, 2019.

https://www.dco.uscg.mil/Our-Organization/Assistant-Commandant-for-Prevention-Policy-CG5P/Commercial-Regulations-standards-CG5PS/Office-of-Standards-Evaluation-and-Development/Regulatory-Links/.

Office of the Federal Register. "A Guide to the Rulemaking Process." Office of the Federal Register. Accessed April 20, 2019. https://www.federalregister.gov/uploads/2011/01/the rulemaking process.pdf. 
Osborne, E., J. Richter-Menge, M. Jeffries. 2018. "Executive Summary" in Arctic Report Card: Update for 2018. Compiled by National Oceanic and Atmospheric Administration. November 13, 2018. https://www.arctic.noaa.gov/Report-Card/Report-Card-2018/ArtMID/7878/ArticleID/772/Executive-Summary.

Peter G. Peterson Foundation, ed. "Understanding the Budget." Peter G. Peterson Foundation. Accessed April 19, 2019. https://www.pgpf.org/finding-solutions/understanding-the-budget.

Huntington, H. P., Ph.D. 2011. "Addressing Major Gaps in Arctic Science." Pew. Last modified September 26, 2011. https://www.pewtrusts.org/en/research-and-analysis/fact-sheets/2011/09/26/ addressing-major-gaps-in-arctic-science.

Protection of the Arctic Marine Environment. 2009. "ARCTIC MARINE SHIPPING ASSESSMENT (AMSA)." PAME. Last modified 2009. https://www.pame.is/index.php/projects/arcticmarine-shipping/amsa.

Significant adverse environmental effects., 15 C.F.R. § 970.701 0. Accessed April 20, 2019. https://www.law.cornell.edu/cfr/text/15/970.701.

Stokke, O. S. 2012. "Political Stability and Multi-level Governance in the Arctic" in Environmental Security in the Arctic Ocean. Compiled by The NATO Science for Peace and Security Programme. Edited by Paul Arthur Berkman and Alexander N. Vylegzhanin, 297-311, NATO Science for Peace and Security Series - C: Environmental Security. Cambridge, UK: Springer.

Tingstad, A., Scott, S., Van Abel K., Dulani, W, Anania., Ziegler. K., M. D, Davenport, A.C, \& Costello, K. 2017, Identifying Potential Gaps in U.S. Coast Guard Arctic Capabilities. Compiled by U.S. Coast Guard. 2017. V

U.S. Energy Information Administration, comp. 2011. The Annual Energy Outlook 2011. April 2011. https://www.eia.gov/outlooks/aeo/pdf/0383(2011).pdf.

U.S. Geological Survey, comp. 2008. Circum-Arctic Resource Appraisal: Estimates of Undiscovered Oil and Gas North of the Arctic Circle. May 2008. https://pubs.usgs.gov/fs/2008/3049/fs20083049.pdf.

United Nations. 1982. "United Nations Convention on the Law of the Sea." Oceans and Law of the Sea United Nations. Last modified December 10, 1982. https://www.un.org/Depts/los/convention agreements/texts/unclos/unclos e.pdf.
United States Department of Commerce. 2020. NOAA Budget Summary 2021. Compiled by NOAA. https://www.noaa.gov/sites/default/files/atoms/files/508\%20Compliant NOAA $\% 20$ FY $21 \% 20$ Budget $\% 20$ Blue $\% 20$ Boo k\%20Summary.pdf.

United States Government Accountability Office. 2014, MARITIME INFRASTRUCTURE Key Issues Related to Commercial Activity in the U.S. Arctic over the Next Decade, Doc. No. 113-14-299, at 1 (Mar. 2014). https://www.gao.gov/assets/670/661761.pdf.

U.S. Army Corps of Engineers. "Alaska District." U.S. Army. Accessed April 20, 2019. https://www.poa.usace.army.mil/Library/Reports-and-Studies/Alaska-Regional-Ports-Study/.

U.S. Department of Commerce. "Office of Policy and Strategic Planning." U.S. Department of Commerce. Accessed April 20, 2019. https://www.commerce.gov/bureaus-and-offices/os/policy-andstrategic-planning.

U.S. Department of Defense. "DoD Regulatory Program." DOD Open Government U.S. Department of Defense. Accessed April 20, 2019. https://open.defense.gov/Regulatory-Program/.

U.S. Department of State. "Arctic." U.S. Department of State. Accessed April 20, 2019. https://www.state.gov/e/oes/ocns/opa/arc/.

U.S. Department of the Interior. "Office of the Executive Secretariat and Regulatory Affairs." U.S. Department of the Interior. Accessed April 20, 2019. https://www.doi.gov/execsec.

U.S. Department of Transportation. "Office of Regulation." Transportation.gov. Accessed April 20, 2019. https://www.transportation.gov/administrations/general-counsel/office-regulation.

U.S. Environmental Protection Agency. "EPA's Role in the Arctic Council." U.S. Environmental Protection Agency. Accessed April 20, 2019. https://www.epa.gov/international-cooperation/epas-role-arctic-council\&sa=D\&ust $=1554827539757000 \&$ usg $=$ AFQjC NH8QeIFyLPb dr RIR7jsimgZTsvQ.

U.S. Environmental Protection Agency. 2019. "Organization Chart for the Office of Policy (OP)." United States Environmental Protection Agency. Last modified April 1, 2019. https://www.epa.gov/aboutepa/organizationchart-office-policy-op. 
Yalowitz, K. S. 2012. "Arctic Climate Change: Security Challenges and Stewardship Opportunities" in Environmental Security in the Arctic Ocean. Compiled by The NATO Science for Peace and Security Programme. Edited by Paul Arthur Berkman and Alexander N. Vylegzhanin, 32. NATO Science for Peace and Security Series - C: Environmental Security. Cambridge, UK: Springer.
Zhang, F. 2017. "Assessing China's response to the South China Sea arbitration ruling." Australian Journal of International Affairs 71, no. 4 (February 28, 2017): 440-59. https://doi.org/10.1080/10357718.2017.12878 76.

Anna Zolyniak is a student at the Walsh School of Foreign Service at Georgetown University studying International Politics and concentrating in International Law. Her primary academic interests are environmental and resource law and policy and the jurisprudence of national and international security. Anna has conducted policy research in the U.S. Arctic and is currently researching international bulk water trade law. Anna also spent time studying abroad in Berlin, Germany and was nominated to serve as a delegate from Georgetown University to the 2020 Worldwide U7+ Student Forum.

\section{Acknowledgements}

I would like to thank Professor Jeremy Mathis for introducing me to the world of the Arctic, for opening my eyes to the changes that are happening there, and for assisting me in writing and reviewing the original draft of this paper. 